\title{
Turizm Politikasının Oluşturulmasında Yönetişim Uygulaması: Türkiye Üzerine Bir Araştırma*
}

\section{Governance Application in Tourism Policymaking: A Research on Turkey}

\author{
Öğr. Gör. Dr. Nurullah Cihan AĞBAY \\ Bitlis Eren Üniversitesi \\ Kanık Uygulamalı Bilimler Yüksekokulu \\ Bitlis, Türkiye \\ E-posta: cihanagbay@gmail.com
}

\author{
Prof. Dr. Yusuf KARAKILÇIK \\ İnönü Üniversitesi \\ İktisadi ve İdari Bilimler Fakültesi \\ Malatya,Türkiye \\ E-posta: yusuf.karakilcik@inonu.edu.tr
}

Öz

Bu çalışmanın temel amacı, Türkiye'de turizm politikası oluşturulması sürecinde yönetişimin uygulanıp uygulanmadığını araştırmaktır. Araştırma sorusuna cevap verebilmek için nitel bir yaklaşım olan fenomenolojik (olgu bilim) araştırma deseni ve amaçlı örneklem kapsamında ölçüt örneklem kullanılmıştır. Bu bağlamda, araştırmaya turizm politikası oluşturma sürecinde rol oynayabilecek turizm paydaşları dâhil edilmiştir. Yarı yapılandırılmış görüşme tekniği kullanılarak yedi ayrı paydaş temsilcisi ile yüz yüze görüşme gerçekleştirilmiş ve toplanan veriler betimsel analiz yöntemi ile analiz edilmiştir. Araştırma verileri çalışmada açıklanan literatüre uyumlu olacak şekilde kodlanmış ve nitel veri analizi programı yardımı ile temalara ilişkin kod haritaları oluşturulmuştur. Çalışmanın sonucunda, Türkiye'de turizm politikası oluşturma sürecinde; paydaşlara göre farklı düzeylerde katılımcılığın sağlandığı, koordinasyon ve işbirliği eksikliğinin olduğu, turizm politikası ve Kültür ve Turizm Bakanlığı'nın aktörlerin talep ve ihtiyaçlarına yeteri kadar cevap vermediği, paydaşlar arasında yeterli şeffaflığın sağlanmadığı ve dolayısıyla bu süreçte etkin bir yönetişimin uygulanmadığı ortaya çıkmıştır.

Anahtar Kelimeler: Turizm Politikası, Yönetişim, Politika Oluşturma, Kamu Politikası, Türkiye.

\begin{abstract}
Main purpose of this study is to investigate whether governance is implemented in tourism policymaking process in Turkey. Phenomenological research design, one of the qualitative approaches, and criterion sampling in the scope of purposeful sampling was used to answer the research question. In this context, tourism stakeholders might play role in tourism policy making process have been included in the study. By using semi-structured interview technique, face to face meeting had been conducted with seven different shareholder agents and gathered datas have been analyzed through descriptive analysis method. Research data have been coded in accordance with the literature explained in the study and code maps related to themes have been created by utilizing qualitative data software. Major conclusions derived from the research are that in tourism policy making process in Turkey, different level of participation by stakeholders is achieved, coordination and collaboration is deficient, tourism policy and Ministry of Culture and Tourism does not adequately respond to the actors' demand and needs, transparency is not adequately provided among the stakeholders, and thereby there is not an efficient governance application on this process.
\end{abstract}

Key Words: Tourism Policy, Governance, Policymaking, Public Policy, Turkey.

*Bu makale Inönü Üniversitesi Sosyal Bilimler Enstitüsü Siyaset Bilimi ve Kamu Yönetimi ABD Yönetim Bilimleri Bilim dalında Prof. Dr. Yusuf KARAKILÇıK danışmanlığında hazırlanan "Türkiye'de Turizm Politikasının Oluşturulmasında Yönetişimin Uygulanabilirliği Üzerine Bir Araştırma” (2019) başlıklı doktora tezinden türetilmiştir. 


\section{Giriş}

Turizm endüstrisinin çok aktörlü bir sistem olması nedeniyle alana ilişkin oluşturulan politikalar, doğal olarak bu aktörleri etkilemektedir. Bir yandan seyahat acenteleri, bir yandan turizm ürünü üreten çalışanların ve rehberlerin, öte yandan otel veya turizm işletmeleri gibi turizm alanlarına yatırım yapanların olması, turizm endüstrisinin karmaşık bir yapı olarak işlemesine neden olmaktadır. Dolayısıyla, aktörlerin politikadan beklentileri de farklılaşabilmektedir. $\mathrm{Bu}$ noktada günümüz yönetim anlayışında özellikle paydaş sayısının çok olduğu turizm endüstrisinin sorunlarını yönetebilmek ve çözebilmek için yönetişim uygulamaları tartışılmakta ve endüstriyel modern toplumlarda karmaşık problemleri yönetebilmek için hükümetler güçlerini gayri resmi aktörlerle paylaşmaktadırlar (Pforr, 2015:146). Turizmin de uzun vadede sürdürülebilmesi, çalışması ve geliştirilebilmesi için paydaşların desteklenmesi gerektiğini ancak bütün paydaşların turizmden aynı derecede çıkar elde etmediğini, bazılarının da politika yapımında ve sonuçlarında daha önemli olduğunu söylemek gerekir (Andriotis ve Stylidis, 2019:9). Örneğin, işçilerin ve belirli bölgede yaşayanların politika yapımında katkıları yok denecek kadar azdır, en iyi intimalle sadece fikirleri alınmaktadır (Joppe, 2018:203). Öte yandan turizm politikalarında özellikle sektör öncülerinin ağırlığı ön plana çıkabilmekte, politikalara da etki edebilmektedirler (Yüksel vd., 2012:513-532; Yüksel vd., 2005:859-886).

Turizme yönelik politikalar veya planlamalar meselelerin neler olduğu, kimlerin dâhil olduğu veya etkilendiği ve uygun alternatif eylemlerin neler olduğu tartışmalarına yer verebilirken, yönetişim ise bunlara genişçe yer verir ve faaliyetlerin tümünü kapsar (Bramwell, 2011). Yönetişim burada bir yandan turizmde aktörler arasındaki işbirliğine imkân tanırken bir yandan da turizmden faydalanan bütün paydaşların ortak amaç ve çıkarlarını belirlemek için bir araç olarak kullanılabilir (Frahm ve Martin, 2009:411).

Türkiye örneğinde turizm politikaları ve yönetişim ilişkisine yapılan sınırlı sayıdaki akademik çalışmalarda tartışmalar genelde politika oluşturmada merkezi hükümetin ağırlığını göstermektedir. Hükümetin rolünün fazla olması (Göymen, 2000: 1025-1048; Nohutçu, 2002; Yüksel vd., 2005:859-886; Özalp-Ateş, 2015) politika oluşturma sürecinde diğer aktör veya paydaşların rollerinin olup olmadığı sorusunu beraberinde getirmektedir. Bu bağlamda çalışmada; "Türkiye'de turizm politikasının oluşturulmasında yönetişimin uygulanıp uygulanmadığı" sorusuna cevap aranmaktadır. Çalışmada öncelikle literatür taraması başlığı altında turizm politikası ve yönetişim kavramları açıklanmış, yöntem bilgisi verilerek, elde edilen bulgulara ilişkin tartışma yapılmış ve son bölümde gelecek araştırmalara öneriler sunulmuştur.

\section{Literatür Taraması}

\subsection{Turizm Politikası}

Kamu politikası "hükümetlerin yapmayı veya yapmamayı seçtikleri her şey" (Dye, 2013:3); ister bir toplum veya daha küçük bir birlik isterse herhangi bir grup için olsun, maddi veya manevi değerleri paylaştıran kararlar ve faaliyetler olarak ifade edilmektedir (Easton, 1959:129-141, 1979:49-50). Daha geniş anlamda ise kamu politikası, toplumsal hedeflere ulaşmak ve toplumsal meseleleri çözmek için tasarlanan ve uygulanan programlara ilişkin siyasi kararlardır (Cochran ve Malone (2010:3-7). Bir kamu politikası örneği olarak turizm politikası da; ' ....kamunun turizm alanına dolaylı veya dolaysız her türlü müdahalesi' (Olalı, 1990:30), turizmi etkilemek için 'hükümet tarafından üstlenilen bilinçli hareketlerin toplamı' olarak tanımlanmaktadır (Garrod, 2012:240). Kapsamlı olarak düşünüldüğünde turizm politikası 'hükümetlerin turizm ile 
ilgili olarak yapmayı veya yapmamayı seçtikleri her şey' şeklinde ifade edilmiştir (Hall ve Jenkins, 1995:7-8). Turizm faaliyetlerinin gerçekleştirildiği yerler açısından ise turizm politikası; özel bir ülke, bölge, çevre veya ayrı bir destinasyonun turizmi geliştirirken harekete geçme yönü (Biederman vd., 2008:460) ya da bir destinasyonda turizmin büyümesine ve geliştirilmesine yönelik ilke, eylem, kılavuz, yönergeler, talimatlar veya prosedürleri kapsayan bir politikadır (Edgell vd., 2008:7; Goeldner ve Ritchie, 2012:326-327). Turizmin çok aktörlü karmaşık yapısı düşünüldüğünde turizm politikası; turizmden yararlanan, hem devlet ve teşebbüsler hem de turist ve turizme ev sahipliği yapan ve bundan gelir elde edenler için en yüksek düzeyde fayda sağlamaya yönelik, turizmin idare edilmesi ve geliştirilmesi faaliyetlerinin bütünü olarak tanımlanabilir. Bu bağlamda, kamu politikasının, sorunları ya da birbiriyle ilişkili problemleri ele almak için kamu makamları tarafından seçilen bir eylem ya da eylemsizlik (Pal, 2006:2) olduğu düşünüldüğünde, turizm politikası da endüstrideki sorunlara çözüm arayacak bir zemin oluşturabilir.

Herhangi bir kamu politikası oluşturma, vatandaşları ve örgütleri amaçlarına ulaşmada etkileyen değişik problemler ve koşullarla toplumların nasıl başa çıkacağına ilişkin hükümetlerin ve diğer politika aktörlerinin soru sorma ve cevap vermelerini içeren politika geliştirme sürecinin bir parçasıdır (Howlett ve Mukherjee, 2017:3). Bu anlamda politika oluşturma, gündemdeki sorunlardan hangilerinin seçileceğini, bu sorunların tanımlanmasını, nedenlerinin neler olduğu ve sonuçlarının neler olabileceği, sorunlara ilişkin öncelik ve amaçların ve bütün bunlar sonunda seçeneklerin neler olduğunun kararlaştırıldığı bir süreçtir (Hogwood ve Gunn, 1991:67-195). Dolayısıyla, politika oluşturma süreci gündemdeki sorunları çözebilmek için bir yandan resmi bir yandan da gayri resmi aktörleri ilgilendirmektedir. Ülkeden ülkeye yönetim sistemleri farklılık gösterse de resmi aktörler yasama, yürütme, yargı ve bürokrasi, gayri resmi aktörler de siyasi partiler, baskı grupları, medya, düşünce kuruluşları ve uluslararası aktörler şeklinde gösterilmektedir (Birkland, 2015; Kaptı, 2013; Çevik ve Demirci, 2015; Poocharoen, 2013; Anderson, 2015a; Dye, 2013; Heywood, 2013; Cahn, 2013).

Turizm politikası da herhangi bir destinasyonun ihtiyaçları, iklim, piyasa, işgücü, tesisler, yerel halk gibi iç ve dış kısıtlar ile ekonomik, sosyal veya kültürel amaçları ve hedefleri dikkate alınarak oluşturulur (Mill ve Morrison, 2012:7; Goeldner ve Ritchie, 2012:339). Resmi aktör olarak hükümet, turizm politikası ile koordinasyon, yasama ve düzenleme, girişimcilik, teşvik etme, planlama faaliyetlerini yapabilir, ekonomik ortamı biçimlendirebilir, turizm için gerekli olan altyapıyı, eğitimi sunabilir, kamu yararını arttırabilir, iş dünyası için düzenleyici çevreyi inşa edebilir, tanıtım ve pazarlamada aktif rol alabilir (Hall, 2005:217-231; Hall, 2009:247). Gayri resmi aktörler de bir yandan turizm ürünlerini üretmede, bir yandan ülke tanıtımına katkı sağlamada, öte yandan turizmdeki çıkarlarını savunmada etkin rol üstlenebilirler.

\subsection{Yönetişim}

Liberal piyasa ekonomisi ve devletin piyasalardaki rolünün azalması ile başlayan yönetişim tartışmaları (Pierre, 2002:1-2; Jessop, 2016:251-253), devletlerin özellikle ulusal politika gibi geniş kapsamlı mekanizmalar için sinerji yaratan, yönetilemeyen durumları yönetme intiyacı sonucu ortaya çıkan, içerisinde farklı tarafları bulunduran organizmaların bu tarafları yönetme sürecine katan bir yöntem olarak (Uçkan, 2010:109) güncelliğini korumaktadır. Kavramsal olarak tek bir tanım içerisine sıkıştırılmayan yönetişim, bir moda, bir sözcük veya bir heves ya da çerçeve çizen, bir köprü, şemsiye olabildiği gibi tanımlayıcı, zor anlaşılan, anlamsız bir kavram, bir yaklaşım, teori ve bir perspektif de olabilmektedir (Levi-Faur, 2014:3). Yönetişim ile yönetme sürecinde birden çok tarafın (aktörün) yer aldığı bir model anlatılmaktadır. Bu 
amaçla yönetişim "sosyal, siyasi ve idari aktörlerin yönetme faaliyetleri" (Kooiman, 1993:2) yani kısaca "yönetme eylemi" olarak tanımlanmaktadır (Hall, 2014:538). Yönetişim faaliyetinin toplumu ilgilendiren tarafına dikkat çeken Meuleman (2008:11) yönetişimi; "toplumsal sorunları çözmek veya toplumsal fırsatlar yaratmayı amaçlayan sivil toplum, özel sektör, kamu kuruluşları ve hükümetin yer aldığı etkileşimin toplamı" olarak tanımlamaktadır. Bu anlamda kamu politikası açısından bakıldığında yönetişim (Capano vd., 2015:313): yönetim sürecinde resmi ve gayri resmi aktörler arasındaki özel ilişkilerin kurulması, arttırılması veya desteklenmesidir. Çünkü yönetişim politika sürecinin hangi düşünce ile ve nasıl koordine edileceğini ve aktörler arasındaki etkileşimi gösterir (Capano vd., 2015:313). Dolayısıyla yönetişim; "Kamu politikasına ilişkin kararların alınması ve uygulanması süreciyle ilgilidir. Farklı sektörlerin (hükümet, kamu sektörü, özel sektör ve sivil toplum) birbirleri arasındaki etkileşimlerin, ilişkilerin ve ağların bir sonucudur. Kimin neyi, ne zaman ve nasıl elde edeceğini belirlemek için paydaşlar arasındaki kararları, müzakereleri ve farklı güç ilişkilerini kapsar" (Choudhary ve Neeli, 2018:247).

\section{Şekil 1: İyi Yönetişim İlkeleri}

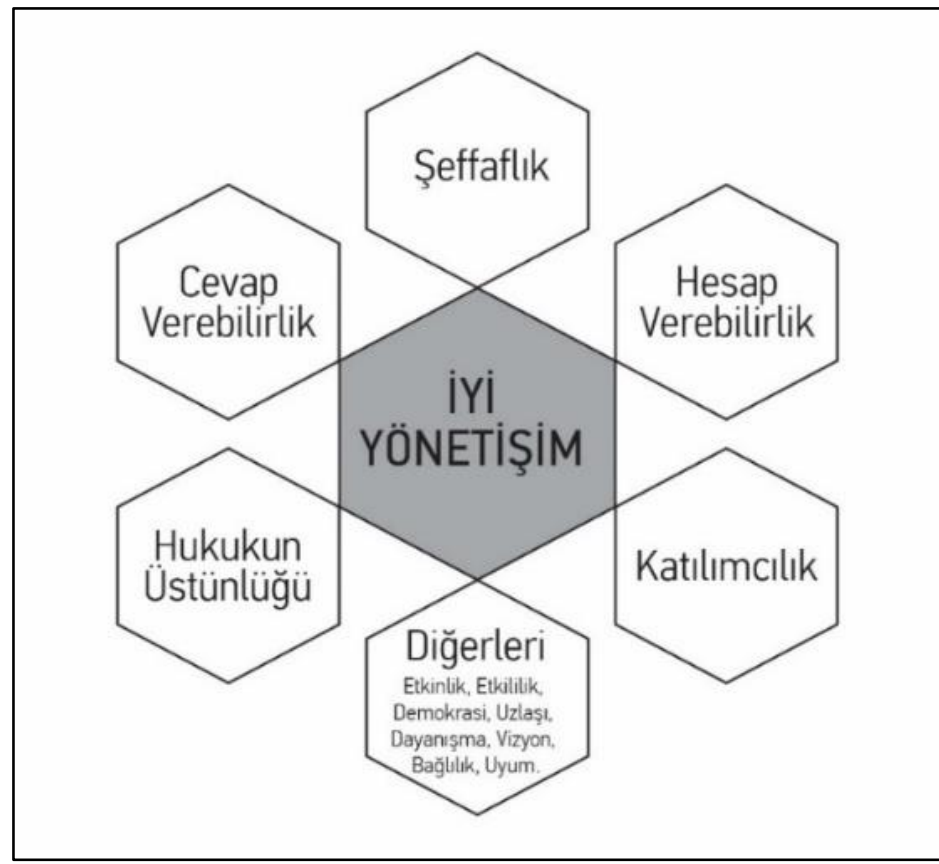

Kaynak: Araştırmacı Tarafından Oluşturulmuştur.

Temel olarak devletlerin yönetim anlayışının değişmesi, toplumsal problemlerin çözülmesi için sivil toplumun ve gayri resmi aktörlerin de dâhil olmasıyla ortaya çıkan yönetişim, içerik olarak kendisini geliştiren bir kavram olmuştur. Örneğin, hükümet, piyasa ve sistem ya da bunların birleşik başarısızlıklarının üstesinden gelinmesi için daha etkili yönetişim sistemlerine olan intiyaca cevap olarak iyi yönetişim kavramı tartışılmaya başlanmıştır (Rogers ve Hall 2003'ten aktaran: Hill, 2013:21-22). Kamu politikaları açısından iyi yönetişim farklı aktörlerin birliğine, özel ve sivil alanın rolüne, bürokrasinin etkililiği ve şeffaflığı, liderlerin hesap verebilmesi ve hukukun üstünlüğü ilkelerine vurgu yapar (Petric ve Blundo, 2012:9). Aslında yönetişimin detaylandırılmış biçimi olan iyi yönetişimi açıklamak için, Şekil 1.'de yer verildiği gibi, Birleşmiş Milletler Kalkınma Programı (aktaran; Choudhary ve Neeli, 2018:251-253), Dünya Bankası (WB: 1989, 1992, 1994) ve Avrupa Komisyonu (aktaran; Okçu, 2007) katılımcılık, 
hukukun üstünlüğü, şeffaflık, cevap verebilirlik, hesap verebilirlik gibi ilkeleri kullanmıştır. Yönetişim alanyazınında farklı kavramlar da kullanılmaktadır: farklı çıkarların gerçekleştirilebildiği uzlaşı, süreçlerde ve kurumlarda kaynakların iyi şekilde kullanımasını ifade eden etkililik ve etkinlik, kadın-erkek bütün grupların toplumun bir parçası olduğunu ve refahlarını arttırabilmelerini gösteren eşitlik ve dâhil olma (Choudhary ve Neeli, 2018:252-253), stratejik vizyon, öngörülebilirlik, tutarlılık, bağlılık, dayanışma, belirlilik, adem-i merkezileşme, temsiliyet, yetkilendirme ve demokrasi vb. (Bakry ve Erliyana, 2018:47; Chang, 2012:10-11). Bu çalışma, yönetişimde kullanılan bu kavramların ayrı ayrı detaylarını verme amacını taşımadığı için alan araştırmasında kullanılan iyi yönetişim ilkeleri aşağıdaki gibi açıklanabilir.

Katılımcılık: Bireysel ve grup paydaşlarının, ihtiyaç duydukları sorunları, politikaları ve çözümleri aktif olarak tanımlamaları ve fikirleri, emekleri veya diğer kaynaklarıyla bu politikaların ve eylemlerin uygulanmasında yer almalarını ifade etmektedir (Herrera vd., 2014:4). Politikada başarılı olmak ve aktörlerin bu süreçteki anlaşmalarını sağlamak için onlara daha fazla yer verilmesi gerekmektedir (Pforr, 2015: 145-160). Yönetişim de bu noktada "farklı değerleri ve meseleleri dâhil ederek bütün birey ve örgütlerin sürdürülebilir turizm yönetişimiyle ilgili olacak şekilde katılımlarını teşvik etmelidir" (Dredge, 2015:82). Bu sürece katılım sadece politikaya etki etme konusunda değil aynı zamanda politika ile ortaya çıkabilecek sürprizleri de en alt seviyeye indirme fırsatı oluşturabilir ve bu nedenle baskı gruplarının politika yapım sürecine katılmaları rasyoneldir (Mazey ve Richardson, 2006:241). Bu anlamda, Türkiye'de de turizm endüstrisinde önemli baskı gruplarının turizm politikası yapım sürecinde yer alması paydaş taleplerinin, düşüncelerinin veya önerilerinin değerlendirilmesi veya dikkate alınması açısından önemlidir.

Koordinasyon: Yönetişim bazen, hükümetin ekonomi veya endüstrinin bir bölümünü koordine etmesini, bazen de ekonomiyi temkinli olarak yönetmesi sürecidir. (Hollingsworth vd., 1994 ve Gamble, 2000'den akt. Pierre ve Peters, 2000:23). Çünkü yönetişim "faaliyetlerinde özerk olan fail (aktör), örgüt ve işlevsel sistemler arasındaki karmaşık ve karşılıklı bağımlılık karşısında oluşturulan koordinasyon mekanizma ve stratejileridir" (Jessop, 2016:241). Koordinasyonun da amacı "turizm sistemindeki temel aktörleri uygun yapı ve süreçlerle iletişimlerini organize etmeleri amacıyla bir araya getirmektir" (Pforr, 2004:87). Bu aşamada, devletin turizm politikasındaki bütün rollerini yerine getirmesi aynı zamanda turizm geliştirme aşamasındaki koordinasyonuna bağlı olduğu için ortak eylem ve koordinasyonu açıklayan yönetişim turizm için bir araç olarak kullanılabilmektedir (Hall, 2005:222-224; Bramwell, 2011:459). Devletin koordinasyon rolünün yanı sıra gayri resmi aktörlerin kendi aralarındaki koordinasyon da strateji geliştirme için gereklidir (Çakar, 2018:786-802).

İşbirliği: Yönetişim yapısı, kamu borcunu azaltma, turizmde örgütler arası ilişkiler, devletin yönetişim temelinde müdahaleciliği gibi konular işbirliğinin bazı nedenleridir ve toplum temelli turizmde, güç ve kurumsal düzenlemelerde, yerel ekonomi geliştirme gibi alanlarda uygulanabilmektedir (Zapata ve Hall, 2012:63-64). Yani yönetişim, ekonomik aktörlerin ortak problemleri ve koordinasyon sorunlarını çözmek için işbirliği yaptığı çeşitli mekanizmaları sunabilir (Pierre ve Peters, 2000:1819). Turizm politikası da farklı birçok paydaşa sahip olduğu için hem paydaşların resmi ve gayri resmi hem de devlet idaresinin resmi olarak süreç içerisinde yer alması kaçınılmazdır. Dolayısıyla, resmi aktörler ve gayri resmi aktörler turizm faaliyetleri sürdürülürken işbirliği içerisinde olmak zorundadırlar. Çünkü işbirliğinin turizmin sürdürülebilir çeşitlerinin büyümesine katkıda bulunma potansiyeli olup (Lovelock, 1999'dan aktaran: Hall, 1999:280) çatışma ve problem çözümü ve kapasite inşa etmede kullanılabilir (Bramwell ve Lane, 1999:180). İşbirliği hem politika oluşturma 
aşamasında hem de yönetişimde başarılı sonuçlar elde etmek için önemli bir boyuttur (Ruhanen vd., 2010; Çakar, 2018:786-802). Kamu ve özel sektör arasındaki işbirliği, turizm geliştirmede özellikle de turistleri tatmin edecek ürünlerle intiyaçlarını gidermede ve turizm bölgelerinde işbirliğini arttırmada stratejik araç olarak da kullanılabilir (PonsMorera vd., 2018:145). Bu anlamda bir bütün olarak eksiksiz bir turizm ürünü üretmek birçok aktörün işbirliğine bağlıdır (Mei vd., 2013:522).

Cevap Verebilirlik: Cevap verebilirlik kamu politikalarının başarısı için önemli yönetişim ilkelerinden birisidir. Birleşmiş Milletler Kalkınma Programı (UNDP) cevap verebilirliği kurumların ve süreçlerin bütün paydaşlara hizmet etmesi ile açıklamaktadır (aktaran; Choudhary ve Neeli, 2018:252). Cevap verebilirlik, kamu yöneticileri ve kamu idarelerinin vatandaşların taleplerine zamanında cevap vermelerini, bu talepleri sebepsiz yere geciktirmemelerini veya hiçbir meseleyi cevap vermeden bırakmamalarını, ihtiyaç duyulduğunda vatandaşlardan tavsiyeler alma ve politikaları onlara açıklama zorunluluğu olduğunu ifade etmektedir (Keping, 2018:6).

Şeffaflık: "Şeffafık memnuniyetle karşılanabilecek ya da rahatsızlık duyulabilecek bilgi veya bilginin paylaşılmasıdır" (Farrell, 2016:445). Şeffaflık bir norm olarak demokrasi ve insan haklarının önemli bir parçasıdır ve vatandaşların yönetişim çerçevesinde neler olup bittiğini bilme hakkını ve hükümetlerin açık olma görevini ifade eder (Dror, 2000:63). Demokrasinin en önemli araçlarından biri olan şeffaflığı her vatandaşın talep etme hakkı vardır (Alloa ve Thomä, 2018:2). Bu nedenle, vatandaşların yönetime olan güvenini arttırmada ve yönetişimi daha etkili hale getirmede kullanılabilir (Erkkilä, 2012:xiv). Şeffaflığın yönetişim sürecinin hatta yönetimin olduğu her yerde: ekonomik veya kurumsal alanlar (Forssbaeck ve Oxelheim, 2015), meslekler, yatırımlar, kâr amacı gütmeyen kuruluşlar veya dini kuruluşlar (Oliver, 2004:7-9) gibi birçok alanda kullanılması gerektiğini belirtmek gerekir.

Alanyazında doğrudan bu ilkelerin değil ancak turizmde yönetişimin farklı açıdan araştırıldığı çalışmalar mevcuttur. Örneğin, rekreasyon alanlarında yönetişim (Eagles, 2009:231-249), Antalya'da kriz dönemlerinde turizm yönetişimi, (Çakar, 2018: 786802), Amsterdam ve Antalya kentleri için yönetişim karşılaştırmaları (Erkuş-Öztürk, 2011:307-325), Antalya için sürdürülebilir turizm yönetişimi (Çizel vd., 2015), Hong Kong'da yapılan, çoğulcu bir yönetim anlayışı, etkileşim ve planlama ilişkisi (Wan ve Bramwell, 2015:316-327) araştırmaları mevcuttur.

Alanyazında turizm politikası ve yönetişim üzerine yapılan çalışmalar da bulunmaktadır. Örneğin, Hall (2011:437-457) turizm politikası sürecinde yönetişim kullanılması için hiyerarşiler, ağlar, topluluklar ve piyasa tipolojilerini önermiştir. Airey ve Ruhanen (2014:144-162) ulusal düzeyde turizm politikasının yapımında paydaşların katılımcılığının önemini, karmaşık süreci, bu süreçte işletmelerin temsiliyetini ortaya çıkarmıştır. Göymen (2000:1025-1048) Türkiye'de yönetişimin erken dönem çalışmalarından biri olarak, turizm politikası sürecinde kamu ağırlığının özel sektöre doğru evrildiğini ifade etmiştir. Türkiye örneğinde yapılan bir başka çalışmada da (Özalp-Ateş, 2015) bir yandan kamu kurumları, bir yandan sivil toplum örgütleri diğer yandan turizm yatıımcılarının 'ağ yönetişimi' modelinde işbirliği geliştirmelerinin, turizmin ulusal çıkarlara daha fazla katkı yapması için gerekli olduğu varsayılmaktadır.

Bu çalışma da kuramsal önerilerin yapıldığı çalışmalardan farklı olarak, herhangi bir model önermek yerine, turizmde söz sahibi olan aktörleri araştırmaya dâhil ederek Türkiye'de turizm politikası oluşturma aşamasında yönetişimin uygulanıp uygulanmadığını araştırmaktadır. Ayrıca alanyazında katılımcılık, koordinasyon, 
işbirliği, cevap verebilirlik ve şeffaflık ilkelerinin uygulamada araştırıldığı çalışmalara rastlanılmamıştır.

\section{Yöntem}

Araştırmanın desenlemesi nitel yaklaşım çeşitlerinden biri olan fenomenolojik (olgu bilim) yöntem esas alınarak yapılmıştır (Creswell, 2018:77). Araştırmaya dâhil edilenler, ölçüt örneklem ile (Veal, 2018:430) baskı gruplarının tepe yöneticileri olarak belirlenmiştir. Bu baskı grupları turizm endüstrisinde en fazla üyeye sahip, uzun yıllar faaliyet gösteren ve meslek örgütlerinin en üst kurumu olma özellikleriyle araştırmaya dâhil edilmiştir. Katılımcılar heterojen örneklem kapsamında (1-10 kişi) belirlenmiştir (Creswell, 2018:78; Starks ve Trinidad, 2007:1375; Baş ve Akturan, 2017:92). Bu kapsamda, Türkiye Otelciler Federasyonu (TÜROFED), Türkiye Otelciler Birliği (TÜROB), Profesyonel Otel Yöneticileri Derneği (POYD), Turist Rehberleri Birliği (TUREB), Turizm Akademisyenleri Derneği (TUADER) yöneticileri araştırmaya dâhil edilmiştir. Ayrıca iki farklı işçi konfederasyonuna bağı Türkiye OLEYis (Türkiye Otel Lokanta Eğlence Yerleri İşçileri Sendikası) ve Türkiye Otel Lokanta Dinlenme Yerleri İşçileri Sendikası (TOLEYIS) yöneticileri de dâhil edilerek toplam 7 (yedi) tepe yöneticisi ile görüşme gerçekleştirilmiştir. Kültür ve Turizm Bakanlığı (KTB) ile resmi, Türkiye Seyahat Acentaları Birliği (TÜRSAB) ile gayri resmi olarak iletişim kurulmasına rağmen, randevu alınamamış ve çalışmaya dâhil edilememeleri önemli bir kısıt olmuştur. Görüşmeler 2019 yılı Ocak ayı içerisinde gerçekleştirilmiş ve görüşmeler ortalama 56 dakika sürmüştür.

\section{Tablo 1: Katılımcıların Demografik Özellikleri}

$\begin{array}{lccccc}\text { Katılımcılar } & \text { Yaş } & \text { Cinsiyet } & \text { Eğitim } & \begin{array}{c}\text { Toplam } \\ \text { Tecrübesi }\end{array} & \begin{array}{c}\text { Kurumdaki } \\ \text { Tecrübesi }\end{array} \\ \text { K1 } & 53 & \text { Erkek } & \text { Lisans } & 34 & 28 \\ \text { K2 } & 50 & \text { Erkek } & \text { Lisans } & 32 & 5,5 \\ \text { K3 } & 69 & \text { Erkek } & \text { Lisans } & 46 & 29 \\ \text { K4 } & 61 & \text { Erkek } & \text { Yüksek Lisans } & 31 & 8 \\ \text { K5 } & 50 & \text { Erkek } & \text { Lisans } & 32 & 13 \\ \text { K6 } & 46 & \text { Erkek } & \text { Doktora } & 24 & 4 \\ \text { K7 } & 43 & \text { Erkek } & \text { Lisans } & 30 & 18\end{array}$

Görüşme yapılan yöneticilerin isimleri belirtilmemiş ve $K 1, K 2, \ldots K 7$ şeklinde kodlanmıştır. Beş ayrı tema oluşturularak, yarı yapılandırılmış görüşme soruları ile veri toplanmış ve veriler betimsel analiz yöntemi ile analiz edilmiştir (Patton, 2018:503; Yıldırım ve Şimşek, 2016:239-240).

Araştırmaya dâhil edilen katılımcılara, görüşme öncesinde okumaları için ilgili çalışmaya yönelik bilgilendirme, konu ve kavramlar hakkında açıklamalar yapılmıştır. Araştırmanın amacının, kimler tarafından yürütüldüğüne ilişkin bilgilerin yer aldığı, araştırmacıların imzalarının bulunduğu, katılımcıların istemediği sorulara cevap vermeme ya da istediği zaman görüşmeden çekilme hakkını ve ses kaydı, görüntü veya not tutulabileceğini, verilerin tamamen bilimsel amaçla kullanılacağını, bilgilerin üçüncü taraflarla paylaşılmayacağını belirten gönüllü katıımcı bilgilendirme formu sunulmuştur. Bu belgeden sonra katılımcılara görüşmeye izin verdiğini ve görüşmenin yapıldığını teyit etmek (kanıtlamak) üzere imzalaması için araştırma başlığı, görüşme tarihi ve katılımcı imzası boşluklarının yer aldığı Katılımcı İzin Formu (Onam) okutularak imza altına alınmış ve muhafaza edilmiştir. 
Konuşmalar profesyonel ses kayıt cihazı ile kaydedilerek metne aktarılmıştır. Katılımcılardan biri ses kaydı alınmasına izin vermemiş ancak görüşme esnasında tutulan notlar görüşme sonunda katılımcıya gösterilerek teyit alınmış ve araştırmaya dâhil edilmiştir. Kayıtlar dikkatli bir şekilde metne aktarılmış, katılımcı görüşlerine halel getirmeyecek ve kelimeler değiştirilmeyecek şekilde gereken yerlerde dilbilgisi ve noktalama işaretleri kullanılarak düzenli hale getirilmiştir.

Nitel araştırmalarda nicel araştırmalarda olduğu gibi sayısal ifadeler yoktur dolayısıyla geçerlik ve güvenirlik daha çok inandırıcılık, tutarlık, inanırlıık, aktarılabilirlik, onaylanabilirlik vb. kavramlar ile açıklanmaktadır (Glesne, 2012:65-66; Miles ve Huberman, 2016:277-280; Başkale, 2016:23-24, Creswell, 2017:201). Bu bağlamda örneğin araştırmanın inandırıcılığı için araştırma verileri turizm yönetişimi konusu çalışan başka bir turizm akademisyeni tarafından incelenerek uzman incelemesi/uzman gözden geçirmesi dolayısıyla da dış denetim (Merriam, 2018:210; Creswell, 2018:252) sağlanmıştır. Olgu ve olaylar araştırmaya tutarlı bir şekilde yansıtılmış ve aktarılabilirliği sağlamak açısından, çalışma sonucunda geçici yargılara ulaşılmış ve gelecek çalışmalar için önerilerde bulunulmuştur (Yıldırım Şimşek, 2016:277-283).

Katılımcılara araştırma konusu ile ilgili açıklamalar yapılarak, sırasıyla yönetişimin katıımcılık, koordinasyon, işbirliği, cevap verebilirlik, şeffaflık temalarıyla ilgili sorular ve verilen cevaplara göre katılımcı görüşlerini derinleştirmek için alt sorular (sonda) sorulmuştur.

\section{Bulgu ve Tartışma}

\subsection{Katılımcılık ile ilgili soru ve cevaplar}

Katılımcılık teması ile turizm endüstrisinde yer alan önemli paydaşların, turizm politikasının oluşturulması sürecine katııp katılmadıklarının ortaya çıkarılması amaçlanmıştır. Bu bağlamda katılımcılara "Turizm politikası oluşturulurken aktörlerin bu sürece yeterli derecede dâhil edildiğini düşünüyor musunuz?" sorusu sorulmuştur. Katılımcı görüşleri:

"Bu konudaki ilk düşüncem çok dâhil edilmiyoruz. Kısmen hani böyle toplantı veya ne bileyim çalıştay gibi şeylere temsilcilerimiz katılıyorlar ancak sadece katılım boyutunda kalmış oluyor...", "Turizm Şurasında da biz...", "Genel olarak çağrılmıyoruz, bazen çağrılıyoruz görüşlerimizi falan açıklıyoruz." (K1)

"Ben kendi açımdan baktığımda yeterince dâhil edildiğini düşünmüyorum dâhil edildiğimiz ortamlarda da biz ciddi çalışmalar yaparak gideriz...”, “...Turizmin gelişmesine yönelik bir şey olsun isteriz çünkü bizim bakış açımız turizm gelişirse ülke gelişir insanlara faydası olur.”, “...oraya götürmüş olduğumuz çalışmaların da nezaketen dinlenildiğini hissediyorum var ama onların devamı getirilmiyor ne yazık ki takibi yapılmıyor o yüzden biz yeterince dâhil edilmiyoruz." (K2)

"Hiç dâhil edilmiyor hiç dâhil edilmiyor...", "ufak tefek toplantılara usulen çağırılıyoruz ama ciddi politikaların tartışıldığı karşsılılı emek ve sermayenin birlikte ne yapabileceği bu ülke için neler yapılabileceğine ilişkin doğru dürüst çalışma Türkiye'de yapılmadı", "Hiç edilmedik hiiiiiç edilmedik ben yani artık bıktım usandım ya..." (K3) 
“...dönem dönem yapılan çalıştaylar işte vesaire bir sürü şeyler var ama bunların uygulanmasında hayata geçirilmesinde sıkıntı son derece fazla...", " ...Şûrada taleplerimiz içinde bu da vardı uzatma talebimiz vardı..." (K4)

"Fikir verme aşamasında evet ama karar verme aşamasında yokuz sonuçta turizm bir devlet politikası." (K5),

“...Şûra var...", "...orada yine aynı şekilde bütün tarafları temsil edecek bir yapı vardı baktığımda bu anlamda bir problem görünmüyor yani”.(K6)

"...geçmişte turizmin ilk başladığı yıllarda çok belirleyici iken sektör kuruluşları şu anda eee yani geçtiğimiz yıllarda çok da belirleyici değiller. Yani çok da onlar evet bir şeyler söylüyorlar ama yine de kamu istediğini istediği şekilde yapıyor" (K7)

Bu değerlendirmelere göre katılımcılık temasının altında 'Turizm Şûrası' (K1K6), 'Çalıştay' (K1-K4), 'İşbirliği'(K3), 'Karşılıklı Etkileşim' (K3), 'Merkezi Yönetimin Ağırlığı'(K5-K7), 'Temsiliyet' (K1-K6) ve 'Kamu Yararı' (K2-K3) kodlamaları yapılmıştır. Araştırmaya dâhil edilen baskı grubu temsilcilerinin turizm politikası oluşturma sürecine kısmen, zaman zaman veya her zaman katıldıkları görülmektedir. Bu durum bütün grupların veya bireylerin politika yapım sürecine katılmak için eşit kapasiteleri olamayabileceğini (Scott vd., 2008:69) veya belirli grupların dışında olan aktörlerin tamamen veya kısmen politika yapım sürecinin dışında kalabildiği durumları göstermektedir (Pforr, 2006:105). Bazı katılımcılar kendilerinin yeterince temsil edilmediklerini belirtmiştir. Benzer olarak Avustralya'da turizm politikası yapımında özellikle endüstri temsilcilerinin ve küçük-büyük işletmelerin temsiliyet sistemi ile bir araya getirilmesinin, seslerinin duyulmasında önemli bir etken olduğu ancak araştırmada politika oluşturma sürecinde paydaşlara dengeli şekilde yer verilmediği sonucuna ulaşılmıştır (Airey ve Ruhanen, 2014:149-162). Bir başka araştırma sonucuna göre de hükümetlerin politika geliştirmede turizm temsilcilerine yer vermesi gerekmektedir (Scott ve Marzano, 2015:181-193).

Türkiye'deki süreçte genel olarak katılım olmasına rağmen bu katılımlar sonucunda arzu edilen politikaların oluşturulamaması yani katılımların politikaya yansıtılamaması eksiklik olarak ifade edilmiştir. Bu durumu Lasswell'in politikanın kimin neyi ne zaman ve nasıl elde edeceği düşüncesi ile bağdaştırmak mümkün olabilir (1936'dan aktaran Almond, 2002:82). Bu çalışmanın 2017-2019 yılları arasında yapılması ve kısıtları göz önünde bulundurulduğunda, erken dönem çalışmalarında yer verildiği gibi (Yüksel vd., 2005; Nohutçu, 2002), Türkiye'de turizm politikası oluşturma sürecinde halen merkezi yönetimin ağırlığı ve yönetişim perspektifinde farklı düzeylerde de olsa katılımcılığın sağlandığı görülmektedir.

\subsection{Koordinasyon ile ilgili soru ve cevaplar}

Yönetişimin bir başka boyutu olan koordinasyona araştırmaya dâhil edilen baskı gruplarının tüzük ve yönetmeliklerinde de yer verilmektedir (Örneğin TÜROFED, TÜROB, TUREB). Bu bağlamda, koordinasyon teması ile turizm endüstrisinde yer alan önemli paydaşlar arasında koordinasyon olup olmadığının ortaya çıkarılması amaçlanmıştır. Katılımcılara "Turizm politikasının oluşturulması sürecinde aktörler arasında koordinasyon eksikliği olduğunu düşünüyor musunuz?" sorusu yöneltilmiştir. Ayrıca, özellikle Kültür ve Turizm Bakanlığı'nın koordinasyon rolünü ortaya çıkarmak için kamunun bu görevi yerine getirip getirmediği ile ilgili alt sorular da sorulmuştur. Katılımcı görüşleri: 
"En büyük eksikliklerden birisi bu. İşveren sendikacılarla bir araya gelmiyor mesela tanıdığımız otel müdürleri bile bizimle artık bir araya gelmiyorlar...", "...Yöneticiler Ankara'ya gelmişler Sous şefler şu kadar para almalıdır diye kendi kendilerine bir miktar belirlemişler aşçılar nerede yok?", "Yani biz iş̧ilerin temsilcisi olarak işçilerin çıkarını korumaya çalışıyoruz ama neye göre ücret belirlendi nasıl belirlendi bilmiyoruz?”, “...eee devlet de Şura toplantılar var işte...” (K1),

"Bugün itibari ile geçmişle karşılaştırıldığında biraz daha ilerleme var koordinasyon anlamında ama bizim tam arzu ettiğimiz koordinasyon hala yok..., “...koordinasyonu sağlayacak hukuki altyapı tam değil...", Birçok kurum kuruluş ondan sonra Bakanlıklar söz sahibi...” (K2)

“Yok tabi canım yok..." (K3)

"Sivil insiyatifte zaten ben şöyle söyleyeyim koordinasyon yok...",....bana sorarsanız özellikle Kültür ve Turizm Bakanlığı yönetişime ve iletişime açık...”, “...bizim tarafımıza baktığımızda sivil toplum tarafında böyle bir dağınık bir örgütlenme yapısı var orada bir modelleme olmadığı için burada da koordinasyonda biraz sıkıntı var tabi ki..." (K4)

"Koordinasyon eksikliği yok da şey var çıkar çatışmaları çok fazla...", "Benim WhatsApp grubum var bütün STK başkanları WhatsApp grubunun üyesi. Hepsi turizm ile ilgili temel paydaşların hepsi WhatsApp grubunda üye..." (K6)

“...Kamu biraz farklı. Yani kamuda bizdeki gibi STK'ların başkanların verdiği destek gibi anında somut destek vermesi mümkün değil çünkü orada bir hiyerarşik zincir var o zincirin içerisinde o Bakanlık işte ilgili yetkili makamlardan izin almadan bir şeye evet ya da hayır demez ama biz genelde olgunlaştırıyoruz." (K6)

“...herkesin farklı rolü var...”, “...farklı çıkar gruplarını temsil ettikleri için...”, "...herkes kendi grubunun çıkarını düşünüyor oysaki turizm politikası dediğimiz şey ne? Aslında ülke turizminin ortak paydasını düşünmek...", "...bizler bu şeyden uzaktayız söylediğimiz bir şeyden uzaktayız o yüzden böyle bir şeyin olmadığını düşünüyorum”, "...Bakanlık koordinasyon kamu temsilcisi olarak ne yapıyor Şûra yapıyor..." (K7)

Bu değerlendirmelere göre koordinasyon teması altında 'Tarafsızlık' (K1), 'Kamu yararı' (K7), 'Çıkar' (K1-K6-K7), 'Sivil Toplum Örgütleri' (K6), 'İletişim' (K4), 'Örgütlenme' (K4), 'Turizm Şûrası' (K7) ve 'Yasal Düzenleme' (K2) kodlamaları yapılmıştır. Koordinasyona ilişkin elde edilen verilere dayanarak, turizm politikası oluşturma sürecinde etkin bir koordinasyonun sağlanmadığı sonucu çıkarılabilir. Katılımcıların bazıları Kültür ve Turizm Bakanlığı'nın bazıları da turizm paydaşlarının koordinasyon sağlayamadığını ifade etmişlerdir. Örneğin K1 kendi çıkarlarını ilgilendiren konularda aktörlerin bir araya gelmediğini herhangi bir koordinasyonun sağlanmadığını ifade etmiş ancak kamu kısmında ise kamunun düzenlemiş olduğu Turizm Şûrası'nı koordinasyon sağlama kapsamında değerlendirmiştir. K4 de sivil aktörler arasında koordinasyon sağlanamadığını ancak özellikle Kültür ve Turizm Bakanlığı'nın iletişime açık olduğunu belirtmiştir. K7 de K1 ve K4'e benzer olarak sivil toplum örgütleri arasında çıkar farklıılklarından dolayı (kamu yararı önceliği) koordinasyonun olmadığını ancak Bakanlığın Turizm Şûrası gibi etkinliklerle koordinasyon sağladığını ifade etmiştir. Alanyazında da kamu yararı Hall (1999: 280285) tarafından paydaşların ve piyasanın çıkarına karşı ortaya çıkabilen bir intiyaç olarak belirtilmiştir. 
K2 özellikle sivil aktörler arasında koordinasyon sağlandığını ancak bunun yeterli seviyede olmadığını, kamu boyutunda ise yasal düzenlemelerin yetersiz olması nedeniyle farklı birçok kamu kuruluşunun sürece dâhil olmasının koordinasyonu zorlaştırdığını ifade etmiştir. K6 gayri resmi aktörler arasında koordinasyon probleminin olmadığını ancak kamunun bürokratik yapısından dolayı koordinasyon sağlamada zorlandığını ifade etmiştir. K3 ayrıca koordinasyon eksikliğinin Kültür ve Turizm Bakanlığı ile iletişim kurulamadığından kaynaklandığını da belirtmiştir. Renn de (2015:8) bu noktada iletişimin paydaşların üretkenliğini arttırabilmeleri ve yönetişim sürecinde yöneticilerin karşılaşabilecekleri muhtemel riskleri azaltabilmeleri, toplumsal intiyaçlara cevap verebilmeleri ve katıımlarının sağlanması için yönetişimde önemli bir ön koşul olarak açıklamaktadır.

\section{3. İşbirliği ile ilgili soru ve cevaplar}

Araştırmaya dâhil edilen turizmin önemli paydaşlarının gerek tüzükleri gerekse amaçları içerisinde turizmde işbirliğini sağlamaya yönelik hedefler bulunmaktadır. Bu aktörlerden Kültür ve Turizm Bakanlığı kültür ve turizm konularıyla ilgili kamu kurum ve kuruşları, yerel yönetimler, sivil toplum örgütleri ve özel sektör ile iletişim ve işbirliği yapmayı görev edinmiştir. Benzer olarak diğer aktörler de kamu, idari makam ve diğer özel sektör kuruluşları ve kişilerle işbirliğini sağlamayı ve sürdürmeyi amaç edinmişlerdir (KTB, TÜROFED, TÜROB, TÜRKIYE OLEYIS, TOLEYIS, POYD, TUADER). Bu amaçla çalışmada da paydaşlar arasında işbirliği olup olmadığı katılımcılara yöneltilen "Turizm politikası oluşturulması sürecinde aktörler arasında yeterli derecede işbirliği olduğunu düşünüyor musunuz?" sorusu ile açıklanmaya çalışılmıştır. Katılımcı görüşleri:

"Şimdi daha iyi. Özellikle son dönemde STK'lardaki değişikliklerden sonra insanlar daha kolay bir araya gelmeye başladı. Başta TÜRSAB olmak üzere TÜROFED zaten her zaman kapısı açıktı evet artık daha açık kapılar insanlar fikirlerini daha iyi daha rahat ifade edebiliyorlar ve daha kolay çözümler üretebiliyorlar." (K5)

"Bence dönemsel olarak var ama genelde yok çünkü tekrar söylüyorum herkes kendi işine konsantre olduğu için”, “...toparlayacak olursak bu sorunuzun cevabı şöyle bunların tamamının oluşması benim şahsi görüşüm ancak menfaat bütünlüğünün sağlanarak temel menfaatin ülke turizmi olduğu algısının kabulü ile oluşacaktır". (K7)

"Tabii elbette çok sıkı işbirliği olduğunu söyleyebilirim yani sadece mesele işbirliğinde koordinasyonda falan problem yok ama herkes kendi işine geldiği gibi biraz daha menfaat çıkarı bir taraf acenteleri temsil ediyor bir taraf otelleri temsil ediyor bir taraf rehberleri temsil ediyor bir taraf yöneticileri temsil ediyor. Dolayısıyla hani oradaki mesela daha çok kendi temsil ettikleri grupların çıkar çatışmaları oluyor", (K6)

"Ben şahsen işbirliği olduğunu düşünmüyorum yani yeterli düzeyde olduğunu düşünmüyorum işte az önce de dedim ya işveren bir araya gelmek istemiyor...", "Bu politikalar sürecinde biz Avrupa birliği ve Uluslararası Çalışma Örgütünün eğitim programları var bütün illerde bu eğitimleri verdik yani onlarla bir işbirliğimiz oldu ama doğrudan politika sürecinde devletle işbirliği olduğunu söyleyebilir miyiz hayır. Yani bugün Avrupa birliği dışarıdan gelen Uluslararası Çalışma Örgütü Türkiye'nin dışındaki örgütler. Ha şunu da söyleyebilirim biz Turizm Bakanlığı'ndan ziyade Çalışma Bakanlığı'nda daha fazla iletişim efendim ilişki geliştirebiliyoruz.”, “...turizm meslek lisesi mezunlarının istihdam edilmesine yönelik sunum yaptık bunları dile getirdik ama burada da bir pek sonuç aldığımız söylenemez. Meslek lisesinde okuyan öğrenciler adeta işlerinde suistimal ediliyorlar normal garson ne yapıyorsa ona da aynı görevi 
veriyorlar veya diğer departmanında çalışan öğrenciler de aynı şekilde hatta ve hatta çoğu yerde işine gelmiyorsa öğrencinin stajını yakarız gibi söylemlerde bile bulunanlar oluyor." (K1)

"Yok ya olsa böyle olur muyuz ya Türkiye'de", "...karşılıklı emek ve sermayenin birlikte ne yapabileceği bu ülke için neler yapılabileceğine ilişkin doğru dürüst çalışma Türkiye'de yapılmadı”, “...bizim genel kurullarımıza dahi Turizm Bakanı gelip bizi dinleme lütfunda bulunmadı...", "Ben Kültür ve Turizm Bakanlığı'ndan artık soğudum bir insanın kapısını bir çalarsın açmaz iki çalarsın açmaz üç çalarsın açmaz dört çalarsın açmaz beş elli defa çaldım kapıyı açan yok", "Mesela burada ILO'nun (uluslararası çalışma örgütü) bir toplantısı oldu ILO üçayaklı bir şey çağırdı işte Çalışma Bakanlığı, sendikalar vardı bir de otelciler vardı..." “...okullardaki otelcilik okullarındaki çocukları getirip orada bedavaya çalıştırıyorlar o çocuklara eğitim yerine bu çok önemli! Eğitim değil hamallık yaptırıyorlar.” (K3)

"Eeeee yeterli düzeyde midir değil aslında bu da şundan yasal düzenlemeler şu anda yetersiz Türkiye'de yani turizm sektörünü. Ondan sonra bu koordinasyonu sağlayacak hukuki alt yapı tam değil. Birçok kurum kuruluş ondan sonra Bakanlıklar söz sahibi...", "Eeee yani turizm sektörünü a'dan z'ye içerecek bir yasal düzenleme şart. O olmadığı sürece yeterli derecede işbirliği olsa bile idare üzerine düşeni yapmadığı zaman yine bir şey elde edemiyorsunuz." (K2)

"Biz sivil insiyatif kısmında mümkün olduğunca bunu yapmaya çalışıyoruz ama kamu tarafı biraz önce de söylediğim gibi kamu tarafı burada şey yaptığı için yetki paylaşımı konusunda özellikle sıkıntı var..." (K4)

$\mathrm{Bu}$ değerlendirmelere göre işbirliği temasının altında 'Dayanışma' (K3), Uluslararası Örgütler' (K1-K3), 'Çıkar' (K6), Yasal Düzenleme' (K2-K4), 'Sivil Toplum Örgütleri' (K5), 'Karşılıklı Etkileşim' (K3-K5), 'Illetişim' (K5), 'Kültür ve Turizm Bakanlığı' (K3), 'Çalışma ve Sosyal Güvenlik Bakanlığı' (K1-K3), 'Kamu Yararı' (K7) ve 'Temsiliyet' (K6) kodlamaları yapılmıştır. Elde edilen bulgulara dayanarak turizm politikası oluşturma sürecinde aktörler arasında etkili bir işbirliğinin sağlanamadığı söylenebilir. Katılımcılardan iki tanesi (K5-K6) hem sivil aktörler hem de resmi aktörlerin işbirliği içerisinde çalıştıklarını, iletişim kanallarının açık olduğunu, özellikle mevcut Kültür ve Turizm Bakanı'nın işbirliğine yakın olduğunu belirtmiştir. Diğer katılımcılardan (K1-K3) işbirliğinin yeterli seviyede olmadığını ancak uluslararası örgütlerle işbirliği sağlanabildiğini ifade edenler de vardır. Bu durum özellikle gelişmekte olan ülkelerdeki politika oluşturma sürecinde uluslararası örgütlere olan saygı ve güveni (McArthur ve Werker, 2016:155-169) ve aynı zamanda politika oluşturma sürecinde uluslararası aktörlerin etkisi olduğunu da desteklemektedir. K3, Bakanlık ile aralarında iletişim ve dayanışma eksikliği olduğunu söyleyerek Beritelli'nin (2011:609) belirttiği gibi destinasyonda paydaşlar arasında dayanışmanın da gerekliliğini göstermiştir. Ayrıca K3'ün karşılıklı etkileşim olarak kodlanan yorumu işbirliği sağlanamamasının nedeni olarak görülebilir. Bu anlamda Çakar (2018) ve Erkuş-Öztürk (2011) tarafından yapılan çalışmalardaki etkileşim eksikliği ile de örtüşmektedir.

Bazı katılımcılar sivil tarafta işbirliğinin kısmen de olsa sağlandığını düşünseler de (K2-K4) farklı kurum ve kuruluşların yetki sahibi olmasını, kendilerini ilgilendiren konularda birden çok kurumla karşı karşıya gelmelerini, dolayısıyla bu anlamda turizmi de kapsayacak bir yasal düzenlemenin olmamasını yeterli seviyede işbirliği sağlanamamasının sebepleri olarak açıklamaktadırlar. Yasal düzenlemenin işbirliğindeki önemi başka bir çalışmada da ortaya çıkarılmıştır (Howes vd., 2015:766). 
Son olarak K6 ve K7 işbirliğinin temsil edilen tarafların çıkarlarını ilgilendiren bir konu olduğunu, işbirliğinin de bundan etkilendiğini ifade etmişlerdir. Farklı çıkarlar nedeniyle yeterli işbirliği sağlanamaması da baskı gruplarının motivasyonlarının kendi çıkarlarına yönelik olması, paydaşlar arasındaki güç dengesizliği veya özel sektörün dar görüşlülüğü ile açıklanabilir (Jamal ve Getz, 1995; Paddison ve Walmsley, 2018:914; Zahra, 2011'den aktaran Amore ve Hall: 2016:115).

\subsection{Cevap verebilirlik ile ilgili soru ve cevaplar}

Araştırmada, turizm politikasının aktörlere cevap verip vermediğini ortaya çıkarmak için katılımcılara 'Turizm politikasının aktörlerin talep ve intiyaçlarına yeteri kadar cevap verdiğini düşünüyor musunuz?' sorusu yöneltilmiştir. Katılımcı görüşleri:

“Vermiyor. Mesela her gelen yeni Bakan'a 25 sayfalık 30 sayfalık sorunlar dosyası hazırlarız bunun içinde mevzuatla ilgili yapılması gereken değişik önerilerimiz de vardır artı bunun yanında da sektörün ihtiyaçlarını belirtiriz biz orada...", "...sorunlar dosyası şeklinde veririz kamuya şöyle bir öneri paketidir o. Siz gelin kısa orta ve uzun vadede sektörün ihtiyaçları bunlardır diye biz veririz. Onu yaptığı zaman otomatikman zaten politika oluşturmuş olacak...”. “...kamu kesiminde Turizm Bakanlığı burada ne kadar istekli de olsa yasa ile belirlenmiş bir sürü şeyleri de olsa Turizm Bakanlığı'nın, diğer kamu kurumlarının bu paylaşımda getirdikleri sıkıntılardan dolayı da yönetişim mantığı da çok fazla çalışmıyor..." (K4)

"Düşünmüyoruz...", "Burada iki türlü düşünmek lazım hep kamuyu da suçlamamak lazım kamu hep suçlu değil.", "Burada talep ettiğiniz birimin de yetkinliği tartışılmalı burada mesela Kültür ve Turizm Bakanlığı şu anda en yetkisiz Bakanlıklardan birisi”, "...mesela birçok işlevini Içişleri Bakanlığı'na devretti. Otellerde tek yetkili otorite iken şu anda otellere girmeyen Bakanlık kalmadı her Bakanlık var hepsi heeepsi girmeyen yok yani...”, “...şimdi bakın 2634'ün içinde çok amir hükümler var teşvikler ile ilgili bakın var elektrik, su, doğalgaz en düşük tarifeden verilir halen yürürlükte 16. Madde duruyor orada. Ihracatçı olduğu halen orada bakın 2019 yılındayız kaç sene önce düşünmüşler ihracat kavramını mefhumunu o zamandan koymuşlar. Teşvik mefhumunu o zamandan koymuşlar. Şimdi siz bunları istediğiniz zaman e talepkâr oluyorsunuz efendim o zaman kaldırın kanundan madem talepkâr oluyoruz o zaman kanunda neden duruyor e kanunda duruyorsa niye uygulanmıyor?" (K7)

"Vallahi bu konuda şunu söyleyebilirim yüzde yirmi beş bizi yüzde yetmiş beş işverenleri ciddiye alıyorlar. Yani bizim normalde yani gerek üyelerimiz gerekse genel olarak sektör çalışanlarıma ilişkin şeylerde sorunlarda genelde olumlu bir dönüş aldığımızı söyleyemem." "...şöyle görüşlerimiz alındı bu görüşleri değerlendirilebilecekleri söylendi ama orada kaldı ne bir gelişme ne bir şey...." "...dile getirdik ancak uzmanlar diğerleri gibi daha doğrusu Bakanlık uzmanları diğer konular gibi değerlendireceğiz dediler orada kaldı." (K1)

"Tatmin etmiyor neden tatmin etmiyor söyledim şimdi ihtiyaçlar yukarıdaki karar vericinin işte bakış açısı baktığı tarafın ihtiyaçları lehine olsun diye değil daha objektif belirlenmeli. Türkiye için belirlenmeli o anlamda şu anda Türkiye için değil işte o bahsettiğimiz paydaşlardan bir grubun lehine biraz daha çıkıyor her seferinde. Dolayısıyla geneli ilgilendirmiyor veya genele ayrıca hitap etmiyor." (K2)

“...Yani ben devletin elinden geleni yaptığı kanaatindeyim. Yani bize bir şey yok gelip gitmiyorlar ama onlara yeterince şey veriyorlar...”, “...Ya turizm yapmak isteyen 
patronlar sermayeye çok kolaylık yaptılar. Türkiye'de 5 yılı ödemesiz bilmem nereye kadar kredi verildi yerlerinden para alınmadı 20-25 yıl işlet sonra gene işlet teşvikler falan...”, “...Ben yanlış bulmuyorum o teşvikler geri döndüğü zaman ben mutlu oluyorum. Bize bir şey yok yapılsın gene onlara yapılsın. Bak teşvikler belki devletin bu işte şimdi teşvikler olmazsa bu iş olmaz bunu kabul etmek lazım. Ha fazla mı? Olsun fazla turizm sektörü bunu getiriyor döviz olarak illa para mı kazandı kazansın ülkenin kazanması önemli." (K3)

“...herkesin ihtiyacına cevap verecek bir politika geliştirmek zaten mümkün değil. Hiçbir yerde mümkün değil kıt kaynaklardan dolayı. Dolayısıyla mutlaka hani bazı paydaşlar bazı dönemlerde daha fazla menfaat sağladıklarını düşünüyor olabilirler bazı dönemlerde başka gruplar sağlayabilir". (K6)

"Bizim yöneticilerimiz ile ilgili ya da Türkiye'de bir otelcilik yasası yok dolayısıyla bunu paylaşabileceğimiz hiçbir bürokratik ortam yok. Biz sadece mesleğimizin, tesislerin bulunduğu bölgelerle ilgili talep ve önerilerimiz var kendi yaptığımız işle ilgili birkaç kez yapıldı ama henüz yasalaşmayan bir konaklama yasası var." "...Bunlar yaklaşık 15-20 yıllık çalışma defalarca gitti geldi ama bir türlü sonuç alınamadı...” (K5)

"Evet, açık o konuda çok rahat ulaşabiliyoruz. Yarın kalkıp da Bakanla görüşemem ama randevu istediğimizde bana sıra geldiğinde mutlaka görüşebiliyoruz o konuda rahatız bütün birimlerle Kaymakamından Valisine Valisinden Bakanına zaman zaman gerektiği zaman hatta çalıştay yapıldığında gittik Sayın Cumhurbaşkanı karşısına bile çıkabildik yani iletişim açık..." (K5)

Cevap verebilirlik temasının altında 'Yasal Düzenleme' (K4-K5), 'Hukukun Üstünlüğü' (K7), 'Öneri' (K4), 'Kültür ve Turizm Bakanlığı' (K1-K4-K7), 'Çalışma ve Sosyal Güvenlik Bakanlığı', 'Yetki' (K4-K7), 'Kamu Yararı' (K2-K3) ve 'Tarafsızlık' (K1K2-K3) kodlamaları yapılmıştır. Elde edilen bulgular ışığında turizm politikasının aktörlerin talep veya ihtiyaçlarına yeteri kadar cevap vermediği söylenebilir. $\mathrm{K} 1, \mathrm{~K} 2$ ve K3 turizm politikasının objektif bir şekilde oluşturulmaması nedeniyle kendilerine yeteri kadar cevap vermediğini belirtirken, $\mathrm{K} 4$ ise her ne kadar paydaş olarak öneriler hazırlasalar da Kültür ve Turizm Bakanlığı'nın yetkilerinin kısıtlı olmasından ve düzenlenen çalıştay gibi etkinliklerin sonuçlarının politikalara yansımamasından dolayı yeterli seviyede cevap alamadıklarını belirtmektedir. Benzer şekilde K7 de Bakanlığın yetkisinin az olduğunu bir problem olarak göstermekte ancak aynı zamanda paydaşların neyi nasıl ne kadar talep ettiklerinin de cevap verebilirlikte etkisi olduğunu ifade etmektedir. Ancak talep ettikleri konuların hukuki dayanakları olmasına rağmen karşılanmadığı durumlar olduğundan da bahsetmiştir. Son olarak K6 da herkesi tatmin edecek bir politika olamayacağını ancak farklı aktörlerin farklı dönemlerde daha fazla fayda sağlayabileceklerini yani bir anlamda tarafsızlığın sağlanamayacağını ifade etmiştir. Literatürde, bu tema altında ortaya çıkan özellikle kamunun tarafsızlığı ile cevap verebilirlik arasındaki ilişki olup olmadığını inceleyen akademik çalışmalara rastlanılmamıştır.

\section{5. Şeffaflık ile ilgili soru ve cevaplar}

Şeffafıı teması ile ilgili olarak katılımcılara "Turizm politikasının oluşturulması sürecinde bilgi, düşünce veya fikirlerin aktörler arasında şeffaf bir şekilde tartışıldığını veya paylaşıldığını düşünüyor musunuz?" sorusu yöneltilmiştir. Ayrıca ulusal turizm örgütü olan Kültür ve Turizm Bakanlığı'nın şeffaflığı hakkında düşünceleri ortaya çıkarmak amacıyla katılımcılara alt sorular sorulmuştur. Katılımcı görüşleri: 
"Tartışılıyor orada hiçbir sıkıntı yok bence. Bakanlık nezdinde de orada bir sıkıntı yok. Her türlü şeyi yapabiliyoruz mesela bizim periyodik olarak çıkan aylık bültenlerimiz var artı raporlama yapıyoruz biz." (K4)

"Bazı şeyleri gizleyebiliyorlar kendilerine özel kendi menfaatleri olacak şeyleri mesela sonradan duyduğumuz çok şey oluyor. Bakanlık şeffaf zaten şeffaf olduklarını düşünüyorum. Bu konuda çok sıkıntı olmuyor bu konuda bir problem olduğunu düşünmüyorum ama mutlaka her yerde vardır şeffaf olmayan gizli görüşmelerle oluşturulmuş politikalar vesaire olabilir ama çok fazla olduğunu düşünmüyorum." (K6)

"Ya bu ortam var tabii ki tartışılıyor aslında. Aktörler arasında tartışılıyor evet konuşuluyor ama tekrar söylüyorum bunlar sonuca ulaşmıyor."(K7)

"Kendi içimizde yani STK'lar arasında bir arada oturduğumuz zaman bürokrasinin olmadığı ortamda bunların hepsini dile getiriyoruz...” (K5)

"Burada çok da öyle bir şey olduğunu düşünmüyorum. Çünkü herkes kendi çıkarından bakıyor olaya.", "...bazen bir bakıyoruz bizim de hiç haberimiz olmayan şeyler bir anda ortaya çıkıyor. Mesela işte toplantılar gibi çalıştaylar gibi yerlerde taleplerimizi söylüyoruz ama herkesin bizim gibi açık olduğuna inanmıyorum." (K1),

"Şeffaf bir şekilde paylaşıldığını düşünmüyorum şöyle düşünmüyorum şimdi eee bazı bilgiler bu taraflardan bir kısmına yarar sağlayabiliyor bir kısmının aleyhine olabiliyor. Dolayısıyla hani çok net bir şekilde ortaya gelip biz şunları istiyoruz veya şu karşı taraf o şekilde tartışılmıyor." (K2)

K4 hem sivil toplum hem de kamu tarafında şeffaflığın sağlandığını ifade etmiş ve bakanlığın buna açık olduğunu belirtmiştir. K5 sivil aktörleri, K6 kamuyu temsil eden Kültür ve Turizm Bakanlığı'nın bunu sağladığına ilişkin olumlu görüş belirtirken K7 tüm tarafların bunu sağladığını ifade etmiştir. K2 bu süreçte şeffaflığın olmadığını burada baskı gruplarının gücünün belirleyici olduğunu Kültür ve Turizm Bakanlığı'nın da bu güce göre şeffaf olduğunu ifade etmektedir. Özetle paydaşların bir kısmı (K4-K5-K6K7) aktör olarak kendilerinin ve kamunun şeffaflığı sağladığını, bir kısmı da (K1 ve K2) gerek aktörlerin kendi aralarında gerekse Bakanlığın şeffaf olmadığını belirtmişlerdir. Şeffaflık teması altında 'Sivil Toplum Örgütleri' (K5-K7), 'Çıkar' (K1), 'İletişim' (K7) ve 'Tarafsızlık (K2)' kodlamaları yapılmıştır.

Literatürde turizm alanındaki kamu kurumlarının veya özel ortaklıklarının şeffaf olmayabildiği (Carrillo-Hidalgo ve Pulido-Fernández, 2019:543-562) veya elitlerin politika yapıcıların eylemleri üzerinde güçlü etkileri olabileceği (Scott vd., 2008:74), turizmin faydalarının şeffaf olarak paylaşıımadığı (Anderson, 2015b:219-220), bazı araştırmalarda da ortaya çıkan sonuçlardır.

\section{Sonuç}

Bu çalışmada, Türkiye'de turizm politikasının oluşturulmasında yönetişimin uygulanıp uygulanmadığı araştırılmıştır. Araştırma nitel yaklaşım ile gerçekleştirilirken, fenomenolojik (olgu bilim) yöntem esas alınarak yapılmış ve Türkiye'de turizm politikası oluşturulmasında yönetişim olgusunu ortaya çıkarmak amacıyla belirlenen paydaşların temsilcileri ile görüşmeler yapılmıştır. Araştırmaya, aktörlerden Ulusal Turizm Örgütü olan Kültür ve Turizm Bakanlığı'nın ve dünyanın büyük seyahat acenteleri birliğinden birisi olan TÜRSAB'ın dâhil edilememesi önemli bir sınırlılık olmuştur. 
Yapılan araştırma ve analizlere dayanılarak çalışmanın ana araştırma sorusu Türkiye'de turizm politikası oluşturulması aşamasında etkin bir yönetişimin uygulanmadığı şeklinde cevaplanabilir. Çünkü belirlenen alt boyutlar itibari ile aktörlere göre farklı düzeylerde olsa da katılımcılığın sağlandığı, koordinasyon ve işbirliği eksikliğinin olduğu, turizm politikasının aktörlerin talep ve ihtiyaçlarına yeteri kadar cevap vermediği ve yeteri kadar şeffaflığın sağlanmadığı ve dolayısıyla bu süreçte etkin bir yönetişimin uygulanmadığı ortaya çıkmaktadır.

\section{Şekil 2: Yönetişim Genel Kod Haritası}

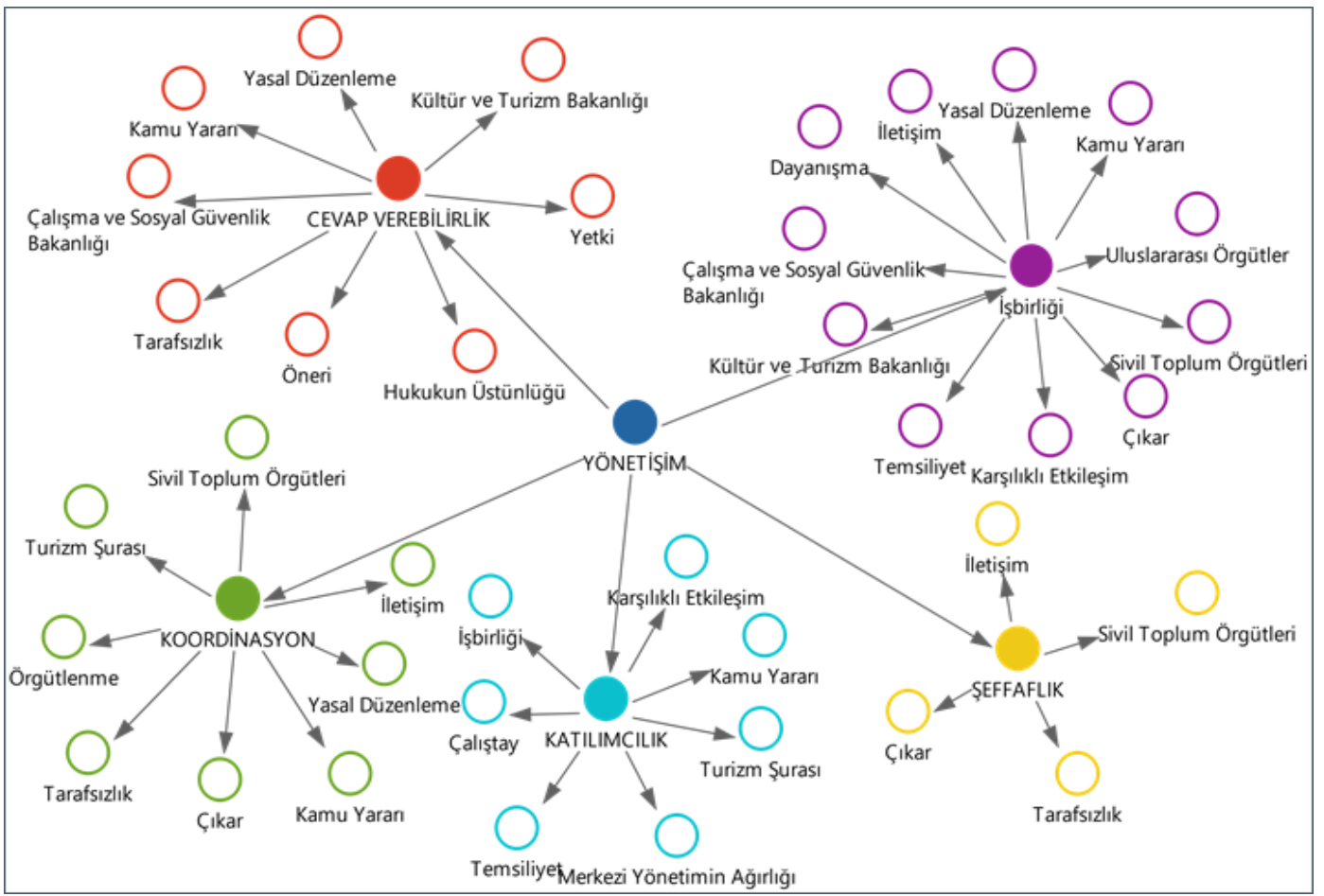

Şekil 2'de görüldüğü gibi alan araştırmasından önce belirlenen yönetişimin alt temalarının ilişkili olduğu kodlamalar elde edilen verilere göre yapılmıştır. Bulgulara göre yönetişimin alt boyutlarını etkileyen sorunların, kesin olmamakla beraber, genel anlamda turizm politikası oluşturulmasında yönetişimin uygulanmasına etki etmekte olduğu ifade edilebilir. Örneğin;

$\checkmark$ Yasal düzenleme eksikliklerinin cevap verebilirlik, koordinasyon ve işbirliği geliştirilmesinde,

$\checkmark$ Aktörlerin çıkar farklılıklarının koordinasyon, şeffaflık ve işbirliği geliştirilmesinde,

$\checkmark$ Tarafsızlığın sağlanmasının koordinasyon, cevap verebilirlik ve şeffafııta,

$\checkmark$ İletişim eksikliğinin şeffaflık, koordinasyon ve işbirliği geliştirilmesinde,

$\checkmark$ Karşılıklı etkileşimin katılımcılığın ve işbirliğinin sağlanmasında,

$\checkmark$ Kamu yararı önceliğinin şeffaflık hariç bütün boyutlarda etkili olduğu söylenebilir.

$\mathrm{Bu}$ araştırmanın nitel bir yaklaşım çerçevesinde hazırlanmış olması ve kısıtları göz önünde bulundurulduğunda aşağıda belirtilen konuların, farklı akademisyen veya uzmanlar tarafından gelecekte nitel yaklaşımların yanı sıra nicel yaklaşımlarla da 
araştırılması, daha bütüncül, kapsayıcı ve derinlemesine analizler yapılmasına katkıda bulunabilir.

\section{Gelecek dönem çalışmaları için öneriler:}

Araştırmada politika oluşturma aşamasında tarafsızlığın eksik olduğu ortaya çıkmıştır. Dolayısıyla, yönetişim ile tarafsızlık arasındaki ilişkinin araştırılması önerilebilir. Farkı aktörlerin ulusal aktörlerle olduğu gibi uluslararası örgütlerle de iletişim ve işbirliği geliştirdikleri görülmektedir. Bu bağlamda, uluslararası örgütlerin turizm politikası oluşturmaya etkisi detaylı olarak araştırılabilir. Bununla birlikte turizm işçi örgütleri, otelci birlikleri, rehberler birliği, turizm akademisyenlerinin turizm politikası oluşturmadaki rolleri ayrı ayrı araştırılabilir.

Araştırmada tarafsızlığı sağlamak için aktörler farklı gruplardan seçilerek araştırmaya dâhil edilmiştir. Ancak araştırılan yönetişim olgusunun daha fazla/farklı aktör veya daha fazla yönetişim alt boyutu göz önünde bulundurularak araştırılması, derinlemesine ve daha kapsamlı çıkarımlar yapabilmek için önerilmektedir. Bu araştırmada ulusal düzeyde politika örneği olarak incelenen turizm politikası bölgesel ölçekte değerlendirilerek, yerel aktörlerin katılımının sağlanmasıyla da değerlendirilebilir. Ayrıca araştırma konusu, Türkiye'de yakın bir zamanda Cumhurbaşkanlığı Hükümet Sistemine geçilmesi nedeniyle, turizm politikaları konusunda sistemin eksikliklerini veya avantajlarını ortaya çıkarmak adına zaman içerisinde tekrar çalışılabilir.

\section{Teşekkür Notu:}

Araştırmaya katılan paydaşların değerli yöneticilerine teşekkür ederiz.

\section{Kaynakça}

Airey, D., \& Ruhanen, L. (2014). 'Tourism Policy-Making in Australia: A National and State Perspective'. Tourism Planning \& Development, 11(2), 149-162.

Alloa, E., \& Thomä, D. (2018). 'Transparency: Thinking Through an Opaque Concept'. Içinde E. Alloa, \& D. Thomä (Eds.)Transparency, Society and Subjectivity: Critical Perspectives (s. 1-14). Switzerland: Palgrave Macmillan.

Almond, G. A. (2002). Ventures in Political Science: Narratives and Reflections. Boulder: Lynne Rienner Publisher.

Amore, A., \& Hall, M. C. (2016). 'From Governance to Meta-Governance in Tourism? Re-Incorporating Politics, Interests and Values in the Analysis of Tourism Governance'. Tourism Recreation Research, 41(2), 109-122.

Anderson, J. E. (2015a). Public Policymaking: An Introduction (8 b.). Stamford: Cengage Learning.

Anderson, W. (2015b). 'Cultural Tourism and Poverty Alleviation in Rural Kilimanjaro, Tanzania'. Journal of Tourism and Cultural Change, 13(3), 208-224.

Andriotis, K., \& Stylidis, D. (2019). 'Introduction'. İçinde K. Andriotis, D. Stylidis, \& A. Weidenfeld (Eds.) Tourism Policy and Planning: Implementation Issues and Challenges (s. 1-21). London and New York: Routledge.

Bakry, M. R., \& Erliyana, A. (2018). 'The Substance of Good Governance Principles on Government Decisions in Indonesia'. İçinde H. Harkrisnowo, H. Juwana, \& Y. U. Oppusunggu Law and Justice in a Globalized World (s. 45-53). London and New York: Routledge.

Baş, T., \& Akturan, U. (2017). Sosyal Bilimlerde Bilgisayar Destekli Nitel Araştırma Yöntemleri (3 b.). Ankara: Seçkin Yayıncılık. 
Başkale, H. (2016). 'Nitel Araştırmalarda Geçerlik, Güvenirlik ve Örneklem Büyüklüğünün Belirlenmesi'. DEUHFED, 9(1), 23-28.

Beritelli, P. (2011). 'Cooperation Among Prominent Actors in a Tourist Destination'. Annals of Tourism Research, 38(2), 607-629.

Biederman, P. S., Lai, J., Laitamaki, J. M., Messerli, H. R., Nyheim, P. D., \& Plog, S. C. (2008). Travel and Tourism: An Industry Primer. Upper Saddle River: Pearson Prentice Hall.

Birkland, T. A. (2015). An Introduction to the Policy Process : Theories, Concepts, and Models of Public Policy Making (3 b.). New York: Routledge.

Bramwell, B. (2011). 'Governance, The State and Sustainable Tourism: A Political Economy Approach'. Journal of Sustainable Tourism, 19(4-5), 459-477.

Bramwell, B., \& Lane, B. (1999). 'Editorial'. Journal of Sustainable Tourism, 7(3-4), 179-181.

Cahn, M. A. (2013). 'Institutional and Noninstitutional Actors in the Policy Process'. İçinde S. Z. Theodoulou, \& M. A. Cahn Public Policy: The Essential Readings (2 b., s. 199-206). Boston, USA: Pearson.

Capano, G., Howlett, M., \& Ramesh, M. (2015). 'Bringing Governments Back in: Governance and Governing in Comparative Policy Analysis'. Journal of Comparative Policy Analysis: Research and Practice, 17(4), 311-321.

Carrillo-Hidalgo, I., \& Pulido-Fernández, J. I. (2019). 'Examining the OrganizationalFinancial Structure of Public-Private Destination Management Organizations'. İçinde V. Katsoni, \& M. Segarra-Oña (Eds.), Smart Tourism as a Driver for Culture and Sustainability: Fifth International Conference IACuDiT, Athens 2018 (s. 543-562). Cham: Springer.

Chang, Y.-C. (2012). Ocean Governance: A Way Forward. Dordrecht: Springer.

Choudhary, C., \& Neeli, S. R. (2018). 'Good Governance to Achieve Resiliency and Sustainable Development'. İçinde I. Pal, \& R. Shaw (Eds.), Disaster Risk Governance in India and Cross Cutting Issues (s. 245-259). Singapore: Springer.

Cochran, C. L., \& Malone, E. F. (2010). Public Policy: Perspectives and Choices (4 b.). London: Lynne Rienner Publishers.

Creswell, J. W. (2017). Araştırma Deseni: Nitel, Nicel ve Karma Yöntem Yaklaşımları (3 b.). (S. B. Demir, Çev.) Ankara: Eğiten Kitap.

Creswell, J. W. (2018). Nitel Araştırma Yöntemleri: Beş Yaklaşıma Göre Nitel Araştırma ve Araştırma Deseni (4 b.). (M. Bütün, \& S. B. Demir (Ed.), Çev.) Ankara: Siyasal Kitabevi.

Çakar, K. (2018). 'Critical Success Factors For Tourist Destination Governance in Times of Crisis: A Case Study of Antalya, Turkey'. Journal of Travel \& Tourism Marketing, 35(6), 786-802.

Çevik, H. H., \& Demirci, S. (2015). Kamu Politikası: Kavramlar, Aktörler, Süreç, Modeller, Analiz, Karar Verme (3 b.). Ankara: Seçkin Yayıncılık.

Çizel, B., Ajanoviç, E., \& Çakar, K. (2016). 'Prerequisites For Effective and Sustainable Destination Governance'. Anatolia, 27(2), 155-166.

Dredge, D. (2015). 'Tourism and Governance'. İçinde G. Moscardo, \& P. Benckendorff (Eds.), Education for Sustainability in Tourism: A Handbook of Processes, Resources, and Strategies (s. 75-90). Heidelberg: Springer.

Dror, Y. (2000). 'Transparency and Openness of Quality Democracy'. İçinde M. Kelly, Oppennes and Transparency in Governance: Challenges and Opportunities (s. 62-71). Bratislava and Maastricht: NISPAcee and EIPA.

Dye, T. R. (2013). Understanding Public Policy. USA: Pearson Education, 14th Edition.

Eagles, P. F. (2009). 'Governance of Recreation and Tourism Partnerships in Parks and Protected Areas'. Journal of Sustainable Tourism, 17(2), 231-248. 
Easton, D. (1959). The Political System: An Inquiry Into The State of Political Science. New York: Alfred A. Knopf.

Easton, D. (1979). A Framework for Political Analysis. Chicago: The University of Chicago Press.

Edgell, D. L., Allen, M. D., Smith, G., \& Swanson, J. R. (2008). Tourism Policy and Planning: Yesterday, Today and Tomorrow (1 b.). (Elsevier, Dü.) Oxford: Butterworth-Heinemann.

Erkkilä, T. (2012). Government Transparency Impacts and Unintended Consequences. Hampshire: Palgrave Macmillan.

Erkuş-Öztürk, H. (2011). 'Modes of Tourism Governance: A Comparison of Amsterdam and Antalya'. Anatolia, 22(3), 307-325.

Farrell, M. (2016). 'Transparency'. Journal of Library Administration, 56(4), 444-452.

Forssbaeck, J., \& Oxelheim, L. (2015). The Oxford Handbook of Economic and Institutional Transparency. Oxford: Oxford University Press.

Frahm, K., \& Martin, L. L. (2009). 'From Government to Governance: Implications for Social Work Administration'. Administration in Social Work, 33(4), 407-422.

Garrod, B. (2012). 'Tourism Policy'. İçinde P. Robinson, Tourism: The Key Concepts (s. 240-245). London and New York: Routledge.

Glesne, C. (2012). Nitel Araştırmaya Giriş (4 b.). (A. Ersoy, \& P. Yalçınoğlu, Çev.) Ankara: Anı Yayıncılık.

Goeldner, C. R., \& Ritchie, J. (2012). Tourism: Principles, Practices, Philosophies (12 ed.). New Jersey: John Wiley \& Sons.

Göymen, K. (2000). 'Tourism and Governance in Turkey'. Annals of Tourism Research, 27(4), 1025-1048.

Hall, C. M. (1999). 'Rethinking Collaboration and Partnership: A Public Policy Perspective'. Journal of Sustainable Tourism, 7(3-4), 274-289.

Hall, C. M. (2005). 'The Role of Government in the Management of Tourism: The Public Sector and Tourism Policies'. İçinde L. Pender, \& R. Sharpley (Eds.), The Management of Tourism (s. 217-231). SAGE Publications: London.

Hall, C. M. (2009). 'The Public Policy Context of Tourism Entrepreneurship'. İçinde J. Ateljevic, \& S. J. Page (Eds.), Tourism and Entrepreneurship: International Perspectives (s. 243-263). Oxford: Butterworth-Heinemann.

Hall, C. M. (2011). 'A Typology of Governance and Its Implications for Tourism Policy Analysis'. Journal of Sustainable Tourism, 19(4-5), 437-457.

Hall, C. M. (2014). 'Introduction: Tourism Policies, Planning, and Governance'. İçinde A. A. Lew, C. M. Hall, \& A. M. Williams, The Wiley Blackwell Companion to Tourism (s. 542-555). West Sussex: John Wiley \& Sons, Ltd.

Hall, C. M., \& Jenkins, J. M. (1995). Tourism and Public Policy. London and New York: Routledge.

Herrera, P. M., Davies, J., \& Baena, M. P. (2014). 'Principles of Pastoralist Governance and Land Management'. İçinde P. M. Herrera, J. Davies, \& M. P. Baena (Eds.), The Governance of Rangelands Collective action for sustainable pastoralism (s. 1-31). London and New York: Routledge.

Heywood, A. (2013). Politics (4 b.). China: Palgrave Macmillan.

Hill, M. (2013). 'A Starting Point: Understanding Governance, Good Governance and Water Governance. In: Climate Change and Water Governance'. İçinde M. Hill, Climate Change and Water Governance: Adaptive Capacity in Chile and Switzerland (Cilt 54, s. 17-28). Dordrecht: Springer.

Hogwood, B. W., \& Gunn, L. A. (1991). Policy Analysis for the Real World (ELBS Edition). Oxford: Oxford University Press.

Howes, M., Tangney, P., Reis, K., Grant-Smith, D., Heazle, M., Bosomworth, K., \& Burton, P. (2015). Towards Networked Governance: Improving Interagency Communication and Collaboration for Disaster Risk Management and Climate 
Change Adaptation in Australia. Journal of Environmental Planning and Management, 58(5), 757-776.

Howlett, M., \& Mukherjee, I. (2017). 'Policy Formulation: Where Knowledge Meets Power in the Policy Process'. İçinde M. Howlett, \& I. Mukherjee, Handbook of Policy Formulation (s. 3-22). Massachusetts, USA: Edward Elgar Publishing Limited.

Jamal, T. B., \& Getz, D. (1995). 'Collaboration Theory and Community Tourism Planning'. Annals of Tourism Research, 22(1), 186-204.

Jessop, B. (2016). Devlet: Dün, Bugün, Gelecek. (A. Güney, Çev.) Ankara: Epos Yayınları.

Joppe, M. (2018). 'Tourism Policy and Governance: Quo Vadis?', Tourism Management Perspectives, 25, 201-204.

Kaptı, A. (2013). 'Kamu Politikası Sürecinde Klasik Yaklaşım Modeli'. A. Kaptı içinde, Kamu Politikası Süreci: Teorik Perspektifler, Modeller, Analiz Yöntemleri (2 b., s. 25-46). Ankara: Seçkin Yayıncılık.

Keping, Y. (2018, March). 'Governance and Good Governance: A New Framework for Political Analysis'. Fudan Journal of the Humanities and Social Sciences, 11(1), 1-8.

Kooiman, J. (1993). 'Social-Political Governance: Introduction'. İçinde J. Kooiman (Ed.), Modern Governance: New Government-Society Interactions (s. 1-6). London: SAGE Publications.

KTB. (2018). 'Kuruluş Amacı ve Görevleri'. http://www.kultur.gov.tr/TR-96130/kurulusamaci-ve-gorevleri.html (10.11.2018).

Levi-Faur, D. (2014). From "Big Government" to "Big Governance". İçinde D. Levi-Faur (Ed.), The Oxford Handbook of Governance (s. 3-18). Oxford: Oxford University Press.

Mazey, S., \& Richardson, J. (2006). 'Interest Groups And Eu Policy-Making: Organisational Logic And Venue'. İçinde J. Richardson, European Union: Power and Policy Making (3 b., s. 239-260). New York, USA: Routledge.

McArthur, J. W., \& Werker, E. (2016, June). 'Developing Countries and International Organizations: Introduction to the Special Issue'. The Review of International Organizations, 11(2), 155-169.

Mei, X. Y., Arcodia, C., \& Ruhanen, L. (2013). 'Innovation and Collaboration: The Role of the National Government in Norway'. Tourism Analysis, 8(5).

Merriam, S. B. (2018). Nitel Araştırma: Desen ve Uygulama İcin Bir Rehber. (S. Turan, Çev.) Ankara: Nobel Akademik Yayıncılık.

Meuleman, L. (2008). Public Management and the Metagovernance of Hierarchies, Networks and Markets: The Feasibility of Designing and Managing Governance Style Combinations. Heidelberg: Physica-Verlag.

Miles, M. B., \& Huberman, M. A. (2016). Nitel Veri Analizi (2 b.). (S. Akbaba Altun, \& A. Ersoy (Ed.), Çev.) Ankara: Pegem Akademi.

Mill, R. C., \& Morrison, A. M. (2012). The Tourism System. USA: Kendall Hunt Publishing Company.

Nohutçu, A. (2002). Evolution of Public Policymaking Within the Dynamics of Governance in the Field of Tourism: the Turkish Case. Middle East Technical University, The Graduate School of Social Sciences, PhD Thesis.

Okçu, M. (2007). 'Yönetişim Tartışmalarına Katkı: Avrupa Birliği İçin Yönetişim Ne Anlama Geliyor?', Süleyman Demirel Üniversitesi Iktisadi ve Idari Bilimler Fakültesi Dergisi, 12(3), 299-312.

Olalı, H. (1990). Turizm Politikası ve Planlaması. (İ. Ü. Yayını, Dü.) İstanbul: Yön Ajans.

Oliver, R. E. (2004). What is Transparency? United States of America: The McGrawHill Companies. 
Özalp-Ateş, S. (2015, February). Network Governance Model in Tourism Administration: a Case Of Turkey. Middle East Technical University, The Graduate School of Social Sciences, PhD Thesis.

Paddison, B., \& Walmsley, A. (2018). 'New Public Management in Tourism: A Case Study of York'. Journal of Sustainable Tourism, 26(6), 910-926.

Pal, L. A. (2006). 'Beyond Policy Analysis: Public Issue Management in Turbulent Times'. Canada: Nelson.

Patton, M. Q. (2018). Nitel Araştırma ve Değerlendirme Yöntemleri (2 b.). (M. Bütün, \& S. B. Demir (Ed.), Çev.) Ankara: Pegem Akademi.

Petric, B., \& Blundo, G. (2012). 'Introduction: Good Governance and Democracy Promotion: Empirical Perspectives on Transnational Powers'. İçinde B. Petric (Ed.), Democracy at Large: NGOs, Political Foundations, Think Tanks, and International Organizations (s. 1-23). New York: Palgrave Macmillan.

Pforr, C. (2004). 'Policy-Making for Sustainable Tourism'. İçinde F. D. Pineda, \& C. A. Brebbia (Eds.), Sustainable Tourism (s. 83-96). Southampton, Boston: WIT Press.

Pforr, C. (2006). 'Tourism Policy in the Making: An Australian Network Study'. Annals of Tourism Research, 33(1), 87-108.

Pforr, C. (2015). 'Tourism Governance and the Influence of Stakeholder Networks: A Case Study from Western Australia'. İçinde H. Pechlaner, \& E. Smeral (Eds.), Tourism and Leisure: Current Issues and Perspectives of Development (s. 145160). Wiesbaden: Springer Gabler.

Pierre, J. (2002). 'Introduction: Understanding Governance'. İçinde J. Pierre (Ed.), Debating Governance: Authority, Steering, and Democracy (s. 1-11). New York: Oxford University Press.

Pierre, J., \& Peters, B. G. (2000). Governance, Politics and the State. Houndmills: Macmillan Press Ltd.

Pons-Morera, C., Canós-Darós, L., \& Gil-Pechuan, I. (2018, March). 'A Model of Collaborative Innovation Between Local Government and Tourism Operators'. Service Business, 12(1), 143-168.

Poocharoen, O.-O. (2013). Bureaucracy and the Policy Process. İçinde E. J. Araral, \& Vd., Routledge Handbook of Public Policy (s. 331-346). New York: Routledge.

POYD. (2018). https://www.poyd.org/poyd (28.12.2018).

Renn, O. (2015). 'Stakeholder and Public Involvement in Risk Governance'. Int J Disaster Risk Sci, 6, 8-20.

Ruhanen, L., Scott, N., Ritchie, B., \& Tka, A. (2010). Governance: A Review and Synthesis Of The Literature. Tourism Review, 65(4), 4-16.

Scott, N., \& Marzano, G. (2015). Governance of Tourism in OECD Countries. Tourism Recreation Research, 40(2), 181-193.

Scott, N., Baggio, R., \& Cooper, C. (2008). Network Analysis and Tourism: From Theory to Practice. Clevedon: Channel View Publications.

Starks, H., \& Trinidad, S. B. (2007). 'Choose Your Method: A Comparison of Phenomenology, Discourse Analysis and Grounded Theory'. Qualitative Health Research, 17(10), 1372-1380.

TOLEYIS.

'Tüzük': http://www.toleyis.org.tr//sayfam/1724/T\%C3\%BCz\%C3\%BC\%C4\%9F\%C3\%BC m\%C3\%BCz.htm (3.7.2018).

TUADER. (2018). http://www.tuader.org/misyonumuz/ (28.12.2018).

TUREB. (2018). http://www.tureb.org.tr/tr/Page/Detail/62 (25.6.2018).

TÜRKIYE OLEYIS. (2018). Tarihçe: http://www.oleyis.org.tr/sayfa.php?id=5 (3.7.2018).

TÜROB. (2018). 'Türkiye Otelciler Birliği': http://www.turob.com/tr/turob/turob-hakkinda (22.5.2018). 
TÜROFED.

(2018).

'Türkiye

Otelciler

Federasyonu':

http://www.turofed.org.tr/hakkimizda.html (20.5.2018).

Uçkan, Ö. (2010). 'Politika Yapım Süreci ve Yönetişim: Türkiye'de Bilgi Toplumu ve Bilgi Ekonomisi Politikalarının Üretiminde Yönetişim Fobisi'. İçinde M. A. Çukurçayır, H. T. Eroğlu, \& H. E. Uğuz, Yönetişim: Kuram, Boyutlar, Uygulama (s. 107-147). Konya: Çizgi Kitabevi.

Veal , A. J. (2018). Research Methods for Leisure and Tourism (5 b.). Harlow: Pearson Education Limited.

Wan, Y. K., \& Bramwell, B. (2015, October). 'Political Economy and the Emergence of a Hybrid Mode of Governance of Tourism Planning'. Tourism Management, 50, 316-327.

WB. (1989). 'Sub-Saharan Afrika From Crisis to Sustainable Growth: A Long Term Perspective Study'. World Bank. http://documents.worldbank.org/curated/en/498241468742846138/pdf/multiOpag e.pdf (5.11.2018).

WB. (1992). 'Governance and Development'. http://documents.worldbank.org/curated/en/604951468739447676/pdf/multipage.pdf (5.11.2018).

WB. (1994). 'Governance: The World Bank's Experience'. Washington: World Bank. http://documents.worldbank.org/curated/en/711471468765285964/pdf/multiOpag e.pdf (7.8.2018).

Yıldırım, A., \& Şimşek, H. (2016). Sosyal Bilimlerde Nitel Araştırma Yöntemleri (10 b.). Ankara: Seçkin Yayıncılık.

Yüksel, A., Yüksel, F., \& Çulha, O. (2012). 'Ministers' Statements: A Policy Implementation Instrument for Sustainable Tourism?', Journal of Sustainable Tourism, 20(4), 513-532.

Yüksel, F., Bramwell, B., \& Yüksel, A. (2005). 'Centralized and Decentralized Tourism Governance in Turkey'. Annals of Tourism Research, 32(4), 859-886.

Zapata, M. J., \& Hall, C. M. (2012). 'Public-Private Collaboration in the Tourism Sector: Balancing Legitimacy and Effectiveness in Local Tourism Partnerships. The Spanish Case'. Journal of Policy Research in Tourism, Leisure and Events, 4(1), 61-83. 